\title{
MIRLET7A1 wt Allele
}

National Cancer Institute

\section{Source}

National Cancer Institute. MIRLET7A1 wt Allele. NCI Thesaurus. Code C81825.

The human MIRLET 7A1 wild-type allele is located in the vicinity of $9 q 22.32$ and is 79 bases in length. This allele, which encodes MIRLET 7A1 RNA, plays a role in development of many cancers including lung, liver, stomach, ovary, breast, colorectal, melanoma, leukemia, lymphoma, cholangiocarcinoma, glioblastoma, lipoma, myoma, hamartoma, sarcoma, adenoma and squamous carcinoma. 